Developing Critical Language Awareness via Service-Learning for Spanish Heritage $\underline{\text { Speakers }}$

By: Kelly Lowther Pereira

Lowther Pereira, K. (2015). Developing Critical Language Awareness via Service-Learning for Spanish Heritage Speakers. Heritage Language Journal, 12(2), 159-185.

Made available courtesy of the National Heritage Language Resource Center with support from the UCLA International Institute: http://www.heritagelanguages.org/Journal.aspx

\begin{abstract}
:
In recent years a growing number of researchers have urged for the adoption of critical pedagogies for the teaching of Spanish as a heritage language (SHL) in the US (Leeman, 2012; Leeman, Rabin \& Román-Mendoza, 2011). Such critical stances to SHL instruction acknowledge the dynamic interplay between language, power, identity and ideology and aim to develop critical language awareness among students in which students gain an understanding of social hierarchies and language subordination. Merging this critical perspective with approaches that unite SHL learners and communities through service-learning programs (Martinez, 2010; Villa, 2010), the current paper examines how service-learning can accomplish critical pedagogical goals.
\end{abstract}

Bridging the fields of sociolinguistics and language pedagogy, the current study examines data collected over four semesters from student journals, interviews and questionnaires in a university Spanish heritage speakers course with service-learning. Qualitative and quantitative analyses explore students' perspectives on language use, sociolinguistic variation, identity and connectedness to the Latino community. This study demonstrates how service-learning contributes to the development of students' awareness of sociolinguistic and sociopolitical issues affecting local Latino communities and the construction of positive identities. Expanding on sociolinguistic research aimed to better meet the needs of SHL learners (see Carreira, 2003; Potowski, 2005; Martinez, 2003; Valdés, 2001), the current study makes critical pedagogical considerations for SHL instruction, with particular emphasis on how to integrate discussions of sociolinguistic variation and language ideologies into the SHL classroom and how to raise critical language awareness among SHL students through community engagement. Overall, this study addresses the complex relationship between language, power, ideology and identity in SHL instruction.

Keywords: Spanish | heritage | service-learning | critical language awareness | pedagogy | identity | language variation

Article:

***Note: Full text of article below 


\title{
Developing Critical Language Awareness via Service-Learning for Spanish Heritage Speakers
}

\author{
Kelly Lowther Pereira \\ The University of North Carolina at Greensboro
}

\begin{abstract}
In recent years a growing number of researchers have urged for the adoption of critical pedagogies for the teaching of Spanish as a heritage language (SHL) in the US (Leeman, 2012; Leeman, Rabin \& Román-Mendoza, 2011). Such critical stances to SHL instruction acknowledge the dynamic interplay between language, power, identity and ideology and aim to develop critical language awareness among students in which students gain an understanding of social hierarchies and language subordination. Merging this critical perspective with approaches that unite SHL learners and communities through service-learning programs (Martinez, 2010; Villa, 2010), the current paper examines how service-learning can accomplish critical pedagogical goals.

Bridging the fields of sociolinguistics and language pedagogy, the current study examines data collected over four semesters from student journals, interviews and questionnaires in a university Spanish heritage speakers course with service-learning. Qualitative and quantitative analyses explore students' perspectives on language use, sociolinguistic variation, identity and connectedness to the Latino community. This study demonstrates how service-learning contributes to the development of students' awareness of sociolinguistic and sociopolitical issues affecting local Latino communities and the construction of positive identities. Expanding on sociolinguistic research aimed to better meet the needs of SHL learners (see Carreira, 2003; Potowski, 2005; Martinez, 2003; Valdés, 2001), the current study makes critical pedagogical considerations for SHL instruction, with particular emphasis on how to integrate discussions of sociolinguistic variation and language ideologies into the SHL classroom and how to raise critical language awareness among SHL students through community engagement. Overall, this study addresses the complex relationship between language, power, ideology and identity in SHL instruction.
\end{abstract}

KEY WORDS: Spanish, heritage, service-learning, critical language awareness, pedagogy, identity, language variation

Recent research in the field of Spanish as a heritage language (SHL) in the U.S. has aimed to better understand the myriad of complex linguistic, pedagogical, political and socioeconomic factors involved in heritage language (HL) maintenance and education. Increasingly informed by sociolinguistic, anthropological and sociopolitical issues, SHL scholars have sought out new models of bilingualism and perspectives to guide future research and teaching. Key issues in the field that have been brought to the forefront include: the need for critical examination of teaching methodologies and instructional materials (Carreira, 2000, 2003; Lowther Pereira, 2010; Martínez, 2003; Valdés, 1981, 1995, 2001; Villa, 2002), the central role of identity in HL 
maintenance (Fishman, 2006; Potowski, 2012) and the impact of language attitudes and ideologies on HL classroom practices and learning (Leeman, 2012; Leeman \& Martinez, 2007; Lowther Pereira, 2010). Researchers have also called for an increased focus on students' voices in SHL pedagogy and planning (Ducar, 2008), a shift in SHL curricula toward preparation for the professions (Martínez, 2010) and collaboration between universities and HL communities to realize shared goals in social activism and change (Leeman, Rabin, \& Román-Mendoza, 2011).

The current study aims to contribute to the development of critical HL pedagogies by examining how service-learning can meet the diverse pedagogical, affective and professional needs of HL learners while simultaneously benefitting communities. This study is based on data collected from 63 SHL learners from four semesters (2011-2013) of an advanced university-level SHL course with service-learning. Quantitative analysis of questionnaires and qualitative analysis of student reflections provide insight into service-learning's impact on students' linguistic experiences, their ties to the local Latino community and identity. The current study provides essential evidence that service-learning generates critical language awareness, helps students build linguistic confidence and aids in the construction of positive identities, making it an effective critical pedagogy for HL learners.

\section{KEY ISSUES IN SHL EDUCATION RESEARCH}

Research in SHL education has increasingly taken into account important sociolinguistic and sociopolitical issues surrounding language, which has spurred important changes in the focus of SHL research and teaching. Currently, there is a strong demand for language pedagogies and teaching strategies that effectively address the multifaceted linguistic and social challenges facing SHL learners. Learner agency, activity and identity need to become more central to the focus of research on SHL education as we move forward in the $21^{\text {st }}$ century as well as the view of language as practice (i.e., "activity") rather than as fixed "system" (Lynch, 2012, p. 91). Attitudes and motivations in the SHL context must also inform HL teaching methodologies (Ducar, 2012), as well as classroom-based studies of identity, in order to move beyond essentializations and more fully understand the critical connections between language, identity and ethnicity (Potowski, 2012).

Research has demonstrated the crucial role of identity in language learning and maintenance. L2 and HL speakers alike who develop positive identities with the language are more likely to learn and maintain the language (Fishman, 2006). As a number of SHL classroom-based studies have shown, students often carry a positive or negative image of their culture and the language, or language varieties, they speak when they enter the classroom (see Martínez, 2003; Potowski, 2004, among others). Additionally, SHL students may experience increased linguistic insecurity, which can impede language development (Martínez, 2003).

Fundamental to understanding the complex relationship between language and identity in multilingual contexts, like that of SHL in the U.S., is recognizing language as intrinsically linked to relations of power, social structures, speaker identities and language ideologies. The poststructuralist view of identity as fluid, dynamic, multivalent and dialogic in nature, in contrast with early essentialist conceptualizations of identity as fixed and static, highlights the social 
positioning, contestability and mutability of the ways language use and beliefs are deeply embedded in social hierarchies and tied to relations of power (Gal, 1998; Woolard, 1998; Gal \& Woolard, 1995; Blommaert, 1999; Blommaert \& Verschueren, 1998; Kroskrity, 1998).Language, never a neutral phenomenon, can be viewed as forming an integral part of a political economy (Friedrich, 1989; Gal, 1989; Irvine, 1989). Speakers engage in linguistic exchanges and make meaning in a linguistic "marketplace" (Bourdieu, 1991), in which they are characterized by their position within the hierarchical social structure. Some language practices are valued, and possess "symbolic capital," while others are stigmatized, essentially illegitimatized via the process of "symbolic domination," and the production and reproduction of hierarchies of power (Bourdieu, 1991). In the context of SHL, not only is English, the dominant societal language, deemed the legitimate, language of status over the minority language, Spanish, but unequal power relations exist between "standard" Spanish and non-standard varieties of the language.

The imposition of a standard language ideology in the SHL classroom, or the privileging of an idealized academic, prestige variety of Spanish, can cause incongruities with the local varieties students may speak, reproducing linguistic hierarchies and potentially negatively impacting students' linguistic confidence and language maintenance (Leeman, 2005; Lowther-Pereira, 2010; Martínez, 2003; Villa, 1996). Research on this topic has importantly emphasized the need to critically examine the treatment of language varieties in Spanish language textbooks (Ducar, 2009; Leeman \& Martínez, 2007; Lowther Pereira, 2010) and classroom discourse (Lowther Pereira, 2010). Studies on Spanish-English bilinguals in academia (cf. Urciouli, 2008; Achugar \& Pessoa, 2009; Lowther Pereira, 2010; Urciouli, 2008) have exposed how the preference for prestige varieties in educational settings can reproduce negative attitudes toward local Spanish varieties, giving symbolic power to prestige varieties and, thus, reinforcing societal inequalities. This body of research critically points toward the influential roles that sources of authority, like textbooks and instructors, play in the connections between language, identity and ideology, and highlights the need for sociolinguistic discussions about language variation and relations of power in the SHL classroom.

Over the last few decades, the HL literature has differentiated itself from second language (L2) education and identified multiple objectives specific to HL education. The following four principal goals of SHL instruction, put forth by Valdés (1995, 2001), continue to guide many HL programs today: (1) Spanish language maintenance among U.S. Latinos, (2) the acquisition of a prestige variety of Spanish by speakers of other varieties, (3) the expansion of the bilingual range to include formal and academic registers, and (4) the transfer of literacy skills from English to Spanish. As mentioned, the emphasis on the acquisition of a prestige variety, and appropriateness-based approaches in particular, which deem the prestige variety the only variety "appropriate" for academic contexts, have been critiqued by scholars in the field.

Although language programs employing such approaches may appear on the surface to recognize the validity of all language varieties, in reality they help reproduce dominant language ideologies and reinforce existing linguistic hierarchies (Fairclough, 1992; Leeman, 2005). In the same vein, emphasis on the instruction of formal and academic registers of Spanish and the concepttualization of "register" as linked to language "proficiency" has contributed to the view of SHL 
learners as "deficient" speakers in formal styles (Lynch, 2012). In contrast, some studies (cf. Silva-Corvalán, 1994; Sánchez-Muñoz, 2007) have shown that SHL learners do possess complex stylistic repertoires as well as awareness of differences in style. Lynch (2012), therefore, urges SHL researchers not to rely on fixed, dichotomous conceptualizations of language (i.e., 'formal' vs. 'informal' styles) and instead calls for the reframing of HL proficiency as a variable, taskbased phenomenon that manifests speaker agency.

Despite valuable research contributions made on the complex relationship between identity, ideology and students' language, as well as the potential repercussions of teaching approaches focused too narrowly on the acquisition of standard Spanish, recent studies on approaches to language variation in SHL courses has revealed little progress toward the inclusion of sociolinguistically-informed teaching practices. An analysis of course objectives of over 60 SHL syllabi from universities across the country by Beaudrie (2015) finds that, despite appreciation approaches having gained popularity over eradication approaches in recent years, the adoption of sociolinguistically-aware teaching practices has been slow and teaching the standard remains central to most SHL programs.

It is evident that the perception of SHL learners' skills as a "deficit" (Jaffe, 2007) by some educators, and some SHL learners themselves, remains a key issue in the field. Ruiz (1984, 2010), who has long advocated for the rejection of a "language-as-problem" orientation supports the adoption of a "language-as-resource" approach in which minority language communities become essential resources of knowledge and expertise. The shift in orientation toward communities, Ruiz (1984) argues, can contribute to greater HL maintenance and the resolution of current policy and planning challenges in SHL education. Ruiz (1984) states, "Not only could language-competent community members be used to train others; the whole community itself could afford multilingual opportunities to language students" (p. 28). This would likewise address any status issues faced by the language and community. This stance is in line with that of Rivera-Mills (2010), who urges academic institutions to "respond to the societal needs of our state, nation and the world by placing intercultural competence at the center of our curricula and providing opportunities for students and faculty to connect with their surrounding communities" (p. vii).

As highlighted by the literature reviewed here, key issues surrounding identity, language ideologies, sociolinguistic topics and student agency must be addressed by future SHL pedagogies. There is a need for critical SHL approaches that incorporate sociolinguistic topics of language variation in the HL classroom, validate students' language skills and varieties and, thereby, validate students' identities. At the same time, language educators must turn toward our communities as resources of linguistic and cultural diversity that can simultaneously fulfill learning objectives and greater societal needs. The current study fulfills a gap in service-learning research on critical language awareness and identity within the SHL context.

\section{SERVICE-LEARNING FOR HERITAge LANGUAGE LEARNERS}

Before delving into the multitude of benefits of service-learning, it is necessary to provide a definition of service-learning as it is intended in the current study. Service-learning is defined by 
the Office of Leadership and Service-Learning at The University of North Carolina at Greensboro (UNCG), the site of the current study, as "a credit-bearing, educational experience that integrates meaningful community service with academic instruction and reflection to enrich the learning experience, teach civic responsibility, and strengthen communities" (Office of Leadership \& Service-Learning, n.d.). It, thus, aims to enhance academic learning while simultaneously teaching students responsible citizenship and benefitting communities in need.

While service-learning is still quite new to the field of HL education, service-learning initiatives within language programs designed for L2 learners have been implemented and developed over the last few decades. Within this time, service-learning research among L2 learners has highlighted important pedagogical gains from service-learning, particularly in terms of enhancing students' cultural understanding and awareness (Caldwell, 2007; Mollica, Neussel, \& Cedeno, 2004; Thompson, 2012; Zapata, 2011), developing positive attitudes toward the target language and culture (Boyle \& Overfield, 1999; Morris, 2001a, 2001b; Zapata, 2011), and improving students' language proficiency (Beebe \& De Costa, 1993; Varona, 1999). A great deal of the scholarly contributions on service-learning for language programs is concentrated in three major volumes containing collections of essays on this topic: Construyendo Puentes [Building Bridges]: Concepts and Models for Service-Learning in Spanish (Hellebrandt \& Varona, 1999), Juntos: Community Partnerships in Spanish and Portuguese (Hellebrandt, Arries, \& Varona, 2003) and Hispania's Special Focus Issue: The Scholarship of Community Engagement (Hellebrandt \& Jorge, 2013). While the most recent volume, as well as Thompson's (2012) book, Intersection of Service and Learning, are both inclusive of HL learners, empirical studies on Spanish and service-learning have focused mainly on L2 learners and research on HL learners specifically is lacking. Yet, for HL learners, service-learning has the potential to "harness the wealth of knowledge and experiences these students bring to the classroom" (Carreira \& Kagan, 2011, p. 62) and to "help steer them away from linguistic and cultural marginalization and toward linguistic and cultural maintenance” (Leeman, Rabin \& Román-Mendoza, 2011, p. 490).

The incorporation of service-learning in the HL curriculum ties back to ACTFL's National Standards for Foreign Language Teaching, which include the "participation in multilingual communities at home and around the world" in the framework of the 5 Cs: communication, cultures, connections, comparisons, and communities. From their inception, the standards involved input from those in HL instruction (Valdés, 2001) and the goals are relevant for HL teaching (Draper \& Hicks, 2000; Valdés, 2001). In fact, the standards framework provides a useful way of conceptualizing HL learners' strengths and needs, and can help "move beyond a focus on prescriptive grammar, transfer of skills, and basic language maintenance" (Valdés, 2001, p. 66). Moreover, using the standards as a guide in HL teaching can contribute to the expansion of the bilingual range, helping students to "grow in their competence to carry out faceto-face interactions, comprehend live and recorded and extended oral texts, comprehend written texts, and use language in written and oral form to present information to groups of listeners or readers" (Valdés, 2001, p. 66).

This important shift in the Standards toward language use creates a distinctive space for the skills that HL learners bring to the classroom. While the Standards clearly do not describe specific course content or curricular approaches (and instead leave curricular design up to local 
districts and schools to decide), service-learning could encompass a central part of HL curricular design to effectively help achieve the standards. While research on service-learning in the SHL context, specifically, is scarce, service-learning studies on Spanish L2 learners have found success with students' achievement of the 5 Cs. For example, based on analysis of student gains in a Spanish Medical Interpretation course, Weldon and Trautmann (2003) conclude that all students achieve all $5 \mathrm{Cs}$ to some degree as a result of their service-learning experience. Likewise, Lear and Abbott (2008) argue that service-learning aids in the achievement of the 5 Cs in ways that a traditional course without service-learning simply cannot. The authors' study, based on a Spanish Business course with service-learning, demonstrates that learning in the 5 Cs was achieved by all students, although particular strengths varied across the $5 \mathrm{Cs}$ according to students' individual skills and personal interests.

In addition to aiding SHL learners in the achievement of the standards, the real-world context for student learning that service-learning provides important opportunities to overcome many of the challenges specific to this learner group highlighted in the SHL literature. For example, when strategically integrated into the SHL curriculum, service-learning can help accomplish the shift toward a "language-as-resource" approach as opposed to "language-as-deficit." By providing contexts for students to forge new identities and exercise their agency in meaningful linguistic exchanges in the community, service-learning has the potential to address affective and power issues and help learners detach from negative associations linked to linguistic varieties that a curriculum merely focused on the acquisition of a "standard" variety may cause. In this way, service-learning responds to Lynch's (2012) call to shift away from artificial theoretical dichotomies such as informal versus formal register by allowing HL learners to develop different "functions" of language, and enabling more 'activity' or task-oriented approaches and forms of assessment.

Moreover, service-learning can address the dynamic role of attitude and motivation in the HL context. SHL researchers and pedagogues need to adopt a more socioculturally informed framework that recognizes that learners both shape and are shaped by the larger social context (Ducar, 2012). Studies on the main motivators for learners to study the HL, for example, whether intrinsic, extrinsic, integrative, instrumental or other motivational constructs are at play, have yielded mixed results (see Ducar, 2012, for a thorough review of these studies). Service-learning, however, can contend with the intricacies of these multiple motivational factors. On the one hand, service-learning satisfies integrative motivations (see for example, Pelletteiri, 2011). Service-learning can create and/or strengthen connections to the HL community through social interaction with community members and, thus, contribute to identity formation. On the other hand, service activities may fulfill instrumental motivations, particularly if they are coordinated with students' academic and/or professional goals in mind. In fact, a number of language for specific purposes (LSP) courses and programs have incorporated service-learning in fields such as business, law and healthcare (Lafford, Abbott, \& Lear, 2014).

The convergence of LSP and service-learning is owed to the meaningful context service-learning provides for students to acquire specialized vocabulary and develop communicative strategies in their field (Martínez \& Schwartz, 2012). Projects such as Medical Spanish for Heritage Learners, developed at The University of Texas Pan American (UTPA), for example, prepare 
future health care professionals with advanced language skills and develop students' awareness of language-related issues in the health care field (Martinez, 2010). Working toward a shared goal and fulfilling an identified community need, this program improves communication in health care settings in the Spanish-speaking community. Similarly, a Spanish for Medical Purposes course developed by Morin (2010) at the College of New Jersey integrates servicelearning and enables students to discover first-hand the challenges faced by Spanish-speaking community members while increasing their linguistic competence in medical Spanish. This course's service activities are created to improve provider-patient communication and care within the community. Implementation of programs such as those mentioned here is a step forward in preparing Spanish-speaking students for the healthcare professions while fulfilling genuine community needs.

While LSP courses with service-learning prepare students for specific professional goals in mind, service-learning activities in general language courses can also benefit students' professional aspirations. Thompson's (2012) study, for example, found that service-learning provided some students knowledge of professions and careers they had not considered previously. Students also reported that they felt more marketable in their chosen profession due to the communication and culture skills acquired in their service-learning experiences (Thompson, 2012).

Service-learning can help students feel more confident in their language skills as well (for example, see Pelletteiri, 2011). In the case of HL learners, service-learning activities can sometimes provide students with new social contexts for HL use. Experiencing language variation through interaction with linguistically diverse community members also can aid in the development of dialectal awareness and flexibility.

Service-learning projects designed specifically around preserving local community language varieties can be a great way to generate critical language awareness among students. Villa's (2010) community revitalization project at New Mexico State University with Las Esperanzas, for example, emphasizes the importance of local language varieties as students complete oral history projects with community members in Southwest Spanish. Yet, service-learning projects do not necessarily have to be designed as such in order for students to experience first-hand the value of local and contact language varieties. Service activities themselves allow students to interact and form connections with local Latino communities, which combined with meaningful guided reflection on sociolinguistic topics, can generate increased critical language awareness. Reflections, discussions, and other coordinated assignments can help challenge dominant language ideologies and linguistic hierarchies by exposing the cultural and linguistic capital of community and contact varieties of the HL. This, in turn, can also contribute to the development of positive linguistic and cultural identities.

\section{THE CURRENT STUdY}

The current study took place in an advanced SHL course taught by the researcher, at The University of North Carolina Greensboro (UNCG) a medium-sized university located in the Piedmont Triad, North Carolina. The Piedmont Triad, which consists of three major cities in north-central North Carolina: Greensboro, Winston-Salem and High Point, has a total population 
of 1,589,200, making it the 31st largest Combined Statistical Area (CSA) in the country and the 3rd largest in North Carolina, after Raleigh-Durham-Cary and Charlotte-Gastonia-Salisbury (U.S. Census Bureau, 2010).

The area's steadily growing economy over the last few decades has attracted many Hispanic migrants, predominantly in the manufacturing, construction, farming and service sectors (Kochhar, R., Suro, R., \& Tafoya, S., 2005). In fact, the state of North Carolina has one of the fastest growing Hispanic populations in the U.S. and is among eight states whose total Hispanic population more than doubled from 2000 to 2010 (Ennis, Rios-Vargas, \& Albert, 2011). This growing Hispanic population has also led to an increase in university enrollment among Hispanic students and the development of specially designed courses for SHL learners at academic institutions across the state, like that of the present study.

\section{COURSE DESCRIPTION}

The advanced SHL course examined here is the first course in the series of required courses counting toward the undergraduate major in Spanish. In terms of language, the course works to build students' linguistic confidence, increase awareness of sociolinguistic variation and develop students' oral, listening, reading, and writing skills. Service-learning was integrated into the course to enrich students' language and culture experience through engagement with the local Latino community. While the course had previously aimed to develop among students an appreciation for the cultural and linguistic diversity of Hispanic/Latino communities around the world, the focus on local communities was admittedly lacking. Turning to the local community was a logical way to meet the course objectives more successfully and at the same time fulfill an identified community need. For example, the service-learning activities themselves would facilitate raising students' awareness of the linguistic, social, political and economic issues faced by the local Latino community. At the same time, service-learning would increase students' HL use and perhaps offer new social contexts in which to use the HL. It would also allow students to experience the value of their local language varieties in the community, and build confidence in their language skills. Students' language experiences in the community could, in turn, facilitate their exploration of the relationship between language and power and why certain language varieties and practices are valued and others stigmatized. Overall, the integration of servicelearning aimed to help generate students' critical language awareness, help them to challenge dominant language ideologies and construct positive linguistic and cultural identities and attitudes.

As is the case for all UNCG courses that maintain the service-learning marker, the course went through a vigorous redesign process to obtain official approval by the Office of Leadership and Service-Learning. A minimum of 15 hours of service was required of all students enrolled in the course although most students willingly exceeded this minimum number of hours. Students chose from a variety of different types of service-learning activities, including tutoring Latino school children, providing language interpretation and translation services for Latino immigrants, giving presentations to recent immigrants on local community services and resources, organizing heritage cultural events and festivals, and providing mentoring and sports activities for Latino youth. Once students elected a community partner, they were strongly encouraged to continue volunteering with that same partner for the remainder of the semester for consistency. Table 1 
below provides details of the main community partners and the types of services provided to community members.

\section{Table 1.}

Community Partners and Services

\begin{tabular}{|c|c|}
\hline Community Partner & Services \\
\hline $\begin{array}{l}\text { Center for New North } \\
\text { Carolinians }\end{array}$ & $\begin{array}{l}\text { Childcare and activities for children of single moms } \\
\text { while their moms take English classes and attend } \\
\text { workshops; presentations on local community } \\
\text { resources }\end{array}$ \\
\hline Cultural Center of Greensboro & Art classes and cultural events and festivals \\
\hline Salvation Army & $\begin{array}{l}\text { Interpretation and translation } \\
\text { immigrants }\end{array}$ \\
\hline Latino Family Center & Mentoring for Latino youth \\
\hline Thriving at 3 & $\begin{array}{l}\text { Office work (creation of newsletters \& articles, } \\
\text { researching local event information, making } \\
\text { appointments for clients for social services, } \\
\text { doctor's visits, etc.) } \\
\text { Interpretation at client appointments } \\
\text { Childcare and activity planning while Latina } \\
\text { mothers attend weekly workshops and classes }\end{array}$ \\
\hline Reedy Fork Afterschool Program & $\begin{array}{l}\text { After-school program for Latino children \& parents } \\
\text { learning English } \\
\text { Tutoring, toddler care, adult literacy for Latina } \\
\text { mothers }\end{array}$ \\
\hline $\begin{array}{l}\text { Oakwood Forest, Glen Haven } \\
\text { and Avalon Community } \\
\text { Programs }\end{array}$ & $\begin{array}{l}\text { Assistance for newly arrived refugees and } \\
\text { immigrants } \\
\text { Tutoring, field trips, adult education classes, } \\
\text { family-based health and safety forums, family } \\
\text { empowerment activities }\end{array}$ \\
\hline
\end{tabular}

Following the service-learning course design guidelines put forth by Howard (2001), "Principles of Good Practice for Service-Learning Pedagogy," service-learning was fully integrated into all the SHL course's assignments, projects and discussions. For example, students completed a journal of written reflections throughout the semester, as well as various projects pertaining to the Latino communities they were serving, including presentations and a final portfolio that compiled all of their service-learning activities and related course assignments throughout the semester. On a regular basis class time was dedicated to discussing students' experiences, both 
positive and negative, related to their service-learning activities. As a team project, students investigated a linguistic, social, political or economic issue affecting the local community by conducting library research combined with fieldwork (e.g., oral interviews with community members and/or community partners). Students analyzed the issue in detail and presented several possible solutions in the form of a written investigative report. Students also gave oral presentations on these issues to inform their classmates, obtain feedback and generate classroom discussion. Whenever possible, students' service-learning activities and experiences were connected to themes from the textbook readings for reflection and class discussions.

Reflections were completed after each service-learning encounter and students were required to submit at least four of these entries during the semester to be graded as part of the larger portfolio project. Reflections were graded mainly on content and quality of reflection, although feedback was periodically given on grammatical points that impeded comprehension. Although reflections were only submitted to the instructor, content of reflections was regularly discussed in pair work and group discussions. To guide critical reflection of their service-learning activity, students were provided the following three general prompts, adapted from Eyler, Giles and Schmiede (1996): (1) What? (Describe objectively what happened at the service-learning encounter); (2) So what? (Interpret what happened, reflecting on what was learned and making connections to course content, themes and discussions); and (3) Now what? (Discuss how the experience will impact you and/or the community). Students were encouraged to write honestly about their observations, including any thoughts or feelings they had about them.

\section{Methodology \\ Participants}

A total of 63 SHL learners (45 females and 18 males) participated in the study. Participants' age ranged from 18-46 years, with $90 \%$ of students aged 18-22 years. Forty participants were born in the US and 23 were born in Latin America. Students were of diverse cultural backgrounds including Puerto Rican, Colombian, Mexican, Costa Rican, Dominican, Nicaraguan, Venezuelan, Cuban, Salvadoran, Ecuadorian, Chilean, Filipino, Honduran and Spanish. In language background questionnaires, the majority of participants (62\%) self-reported as Englishdominant, while $17 \%$ reported as Spanish-dominant and $21 \%$ equally dominant in both languages. All participants reported speaking Spanish at home with family and the majority also reported watching TV in Spanish and listening to Latin music. Some participants reported speaking Spanish with friends.

\section{Data collection and Analysis}

Data were collected during four semesters in which the SHL course was taught from 2011-2013 and were derived from two primary sources: (1) student questionnaires, and (2) student reflections. Questionnaires provided information regarding participants' language background, language practices and quantitative data pertaining to students' service-learning experiences, including Likert scale questions about students' satisfaction with service-learning, connection to the Latino community before and after service-learning, awareness of community issues, etc. Student reflections, on the other hand, provided qualitative data about students' service-learning experiences. Content analysis (Krippendorff, 2004) of reflection entries was performed to analyze the multiple ways service-learning impacted students' experiences. Content analysis can 
be defined as "a research technique for making replicable and valid inferences from texts (or other meaningful matter) to the contexts of their use" (Krippendorff, 2004, p. 18). In the current study, multiple readings of the texts were performed, allowing for quick and early identification of the most salient themes, as well as less obtrusive themes in subsequent readings of the texts. Within the scope the current paper, data pertaining to themes of language awareness and identities will be presented and discussed.

\section{FINDINGS}

\section{Quantitative Findings}

Results of the questionnaire revealed that approximately $78 \%$ of student participants had not participated in service-learning prior to the SHL course and an overwhelming majority (92\%) reported that they would participate in a service-learning course in the future. It is worth mentioning that those who responded that they would not participate in a service-learning course in the future provided the reason that they felt they did not have enough free time to do so.

As Table 2 below indicates, the majority of students (82\%) agreed that not only did they enjoy service-learning but that they would continue to serve the Latino community. In addition, students reported that the experience helped them better understand the issues affecting the local Latino community (69\%), and that it made a difference in the community (88\%) and in their own lives $(74 \%)$.

\section{Table 2.}

Service-learning Questionnaire ${ }^{1}$

\begin{tabular}{|c|c|c|c|c|c|c|c|}
\hline \multirow{3}{*}{ Statement } & \multicolumn{7}{|c|}{ Percentage of Responses } \\
\hline & \multicolumn{4}{|c|}{ Completely Disagree } & \multicolumn{3}{|c|}{ Completely Agree } \\
\hline & 1 & 2 & 3 & 4 & 5 & 6 & 7 \\
\hline $\begin{array}{l}\text { 1) Overall, I enjoyed my } \\
\text { service-learning/volunteer } \\
\text { experience for this course. }\end{array}$ & $0 \%$ & $0 \%$ & $5 \%$ & $8 \%$ & $19 \%$ & $33 \%$ & $35 \%$ \\
\hline $\begin{array}{l}\text { 2) Prior to my service-learning } \\
\text { experience, I felt a part of the } \\
\text { local Latino community of the } \\
\text { Triad/Greensboro. }\end{array}$ & $17 \%$ & $16 \%$ & $11 \%$ & $22 \%$ & $10 \%$ & $11 \%$ & $13 \%$ \\
\hline $\begin{array}{l}\text { 3) I feel better connected to the } \\
\text { local Latino community of the } \\
\text { Triad/Greensboro because of } \\
\text { my service-learning experience. }\end{array}$ & $3 \%$ & $3 \%$ & $5 \%$ & $14 \%$ & $38 \%$ & $19 \%$ & $17 \%$ \\
\hline $\begin{array}{l}\text { 4) I can identify with the local } \\
\text { Latino community through my } \\
\text { service-learning experience. }\end{array}$ & $10 \%$ & $2 \%$ & $5 \%$ & $8 \%$ & $29 \%$ & $25 \%$ & $22 \%$ \\
\hline
\end{tabular}




\section{Percentage of Responses}

\section{Completely Disagree Completely Agree}

Statement

$12 \quad 3$

\begin{tabular}{lll}
5 & 6 & 7 \\
\hline
\end{tabular}

5) I feel a better sense of belonging to the local Latino community through my service$\begin{array}{lllllll}5 \% & 5 \% & 5 \% & 13 \% & 30 \% & 22 \% & 21 \%\end{array}$ learning experience.

\begin{tabular}{|c|c|c|c|c|c|c|c|}
\hline $\begin{array}{l}\text { 6) My service-learning } \\
\text { experience has helped me to } \\
\text { develop my Latino identity. }\end{array}$ & $8 \%$ & $5 \%$ & $8 \%$ & $21 \%$ & $27 \%$ & $16 \%$ & $16 \%$ \\
\hline $\begin{array}{l}\text { 7) I have a better understanding } \\
\text { of the issues affecting the local } \\
\text { Latino community because of } \\
\text { my service-learning experience. }\end{array}$ & $5 \%$ & $3 \%$ & $6 \%$ & $16 \%$ & $17 \%$ & $25 \%$ & $27 \%$ \\
\hline $\begin{array}{l}\text { 8) I feel I have helped the } \\
\text { Latino community through my } \\
\text { service-learning experience. }\end{array}$ & $3 \%$ & $2 \%$ & $3 \%$ & $14 \%$ & $16 \%$ & $22 \%$ & $40 \%$ \\
\hline $\begin{array}{l}\text { 9) I feel that the service- } \\
\text { learning experience has made a } \\
\text { difference in my life. }\end{array}$ & $3 \%$ & $5 \%$ & $6 \%$ & $11 \%$ & $17 \%$ & $22 \%$ & $35 \%$ \\
\hline $\begin{array}{l}\text { 10) I would like to continue } \\
\text { serving the Latino community } \\
\text { in the future in some way. }\end{array}$ & $2 \%$ & $3 \%$ & $3 \%$ & $10 \%$ & $8 \%$ & $25 \%$ & $49 \%$ \\
\hline
\end{tabular}

Identity and connection to the Latino community. With regard to whether students felt the service-learning experience helped them to develop their Latino identity, over half of participants (58\%) expressed agreement with this statement, while $21 \%$ reported indifference and $21 \%$ of participants disagreed (see Table 2). There are a variety of reasons why some students might have felt indifferent or disagreed with this statement. It is worth mentioning that some of those who disagreed with this statement had completed their service-learning activities in the campus community garden, growing and donating vegetables for those in need, as opposed to engaging in face-to-face experiences with community members. These students signed up for servicelearning when it was first integrated into the course and the initial choice of community partners was limited. Some students' busy class and work schedules conflicted with the community partner's service activity offerings and as a result those students opted to maintain the garden on a flexible schedule. The lack of face-to-face interaction with community members, however, may have impacted these students' service-learning experiences. Furthermore, identity is a complex, multifaceted concept and students' perspectives on what contributes to their sense of self and how they identify themselves can vary greatly. Taking this into account, the current 
study also looks to qualitative data analysis of student reflections to provide further insights into students' notions of identity and the relationship between identity and service-learning.

Approximately $75 \%$ of the students reported feeling a better sense of belonging to the local Latino community as a result of their service-learning experience. Nevertheless, in order to better gauge any shift in the students' sense of connectedness to the community, it is important to analyze the paired responses to the following two statements: (1) "Prior to my service-learning experience, I felt a part of the Latino community," and (2) "I feel a better sense of belonging to the local Latino community through my service-learning experience." The majority of students $(67 \%)$ felt little or no connection to the Latino community prior to their service-learning activities yet $71 \%$ of those students reported feeling better connected to the community after these activities. In addition, students who responded that they had already felt a connection prior to their service-learning experience, importantly, reported feeling even better connected to the Latino community after service-learning. Finally, the small number of student responses indicating little or no connection to the community after service-learning further attests to the efficacy of service-learning in fostering strong connections to the community.

Another interesting finding is that ANOVA revealed that students' dominant language did not significantly affect students' questionnaire responses. Contrary to what might be expected, whether students identified as dominant speakers of Spanish or English, or equally dominant in both languages, did not affect their service-learning experience. As reported in Table 3 below, although students' community activities were primarily conducted in Spanish, students who were English-dominant reported indistinguishable overall results from their Spanish-dominant counterparts for the entire questionnaire. While students who identified as equally dominant in both languages on average reported feeling more connected to the community than their colleagues, the difference between the groups' means was not statistically significant. More importantly, all groups declared feeling more connected to the community after taking the service-learning course. Overall, the data here demonstrate the strong positive impact of servicelearning on students' connection to the local Latino community, regardless of students' dominant language. 


\section{Table 3.}

Difference in Scores for Students Dominant in English, Spanish and Both Languages

\begin{tabular}{|c|c|c|c|c|c|c|c|c|c|}
\hline \multirow[t]{2}{*}{ Statement } & \multicolumn{2}{|c|}{$\begin{array}{l}\text { English } \\
\text { Dominant } \\
(n=39)\end{array}$} & \multicolumn{2}{|c|}{$\begin{array}{l}\text { English and } \\
\text { Spanish } \\
\text { Dominant } \\
(\mathrm{n}=13)\end{array}$} & \multicolumn{2}{|c|}{$\begin{array}{l}\text { Spanish } \\
\text { Dominant } \\
\text { (n=11) }\end{array}$} & \multicolumn{2}{|c|}{ ANOVA } & \multirow[b]{2}{*}{ Sig. } \\
\hline & Mean & SD & Mean & SD & Mean & SD & $\mathbf{F}$ & df & \\
\hline $\begin{array}{l}\text { Overall, I enjoyed my service- } \\
\text { learning/volunteer experience } \\
\text { for this course. }\end{array}$ & 5.77 & 1.16 & 5.92 & 1.32 & 6.09 & .83 & .37 & 2,60 & .696 \\
\hline $\begin{array}{l}\text { Prior to my service-learning } \\
\text { experience, I felt a part of the } \\
\text { local Latino community of the } \\
\text { Triad/Greensboro. }{ }^{a}\end{array}$ & 3.69 & 1.89 & 4.23 & 2.55 & 3.36 & 1.69 & .59 & 2,60 & .558 \\
\hline $\begin{array}{l}\text { I feel better connected to the } \\
\text { local Latino community of the } \\
\text { Triad/Greensboro because of } \\
\text { my service-learning } \\
\text { experience. }{ }^{\text {a }}\end{array}$ & 4.95 & 1.45 & 5.69 & 1.32 & 4.82 & 1.40 & 1.57 & 2,60 & .216 \\
\hline $\begin{array}{l}\text { I can identify with the local } \\
\text { Latino community through my } \\
\text { service-learning experience. }\end{array}$ & 5.13 & 1.72 & 5.08 & 2.29 & 5.00 & 1.34 & .02 & 2,60 & .978 \\
\hline $\begin{array}{l}\text { I feel a better sense of } \\
\text { belonging to the local Latino } \\
\text { community through my } \\
\text { service-learning experience. }^{\text {a }}\end{array}$ & 5.00 & 1.47 & 5.15 & 2.15 & 5.27 & 1.49 & .14 & 2,60 & .872 \\
\hline $\begin{array}{l}\text { My service-learning experience } \\
\text { has helped me to develop my } \\
\text { Latino identity. }{ }^{a}\end{array}$ & 4.69 & 1.62 & 4.62 & 2.22 & 4.55 & 1.51 & .03 & 2,60 & .967 \\
\hline $\begin{array}{l}\text { I have a better understanding } \\
\text { of the issues affecting the local } \\
\text { Latino community because of } \\
\text { my service-learning } \\
\text { experience. }{ }^{\text {a }}\end{array}$ & 5.10 & 1.74 & 5.54 & 1.61 & 5.27 & 1.56 & .33 & 2,60 & .720 \\
\hline $\begin{array}{l}\text { I feel I have helped the Latino } \\
\text { community through my } \\
\text { service-learning experience. }{ }^{\text {a }}\end{array}$ & 5.64 & 1.53 & 5.69 & 1.38 & 5.55 & 1.86 & .03 & 2,60 & .973 \\
\hline $\begin{array}{l}\text { I feel that the service-learning } \\
\text { experience has made a } \\
\text { difference in my life. }{ }^{a}\end{array}$ & 5.28 & 1.70 & 5.85 & 1.46 & 5.36 & 1.86 & .55 & 2,60 & .578 \\
\hline $\begin{array}{l}\text { I would like to continue serving } \\
\text { the Latino community in the }\end{array}$ & 6.07 & 1.20 & 5.62 & 2.06 & 5.73 & 1.62 & .59 & 2,60 & .560 \\
\hline
\end{tabular}
future in some way. ${ }^{\mathrm{a}}$

a Analysis of variance (degrees of freedom). Tukey-Kramer correction for multiple comparisons was not used because we do not reject the hypothesis that the levels' mean scores are equal. 


\section{QuAlitative Findings}

The content analysis of student reflections ${ }^{2}$ in this section provides insight into students' experiences as they initiate and strengthen new relationships with local Latino community members and work toward community goals of educating and children and parents and helping families in their transition to the US. The analyses of excerpts that follow highlight students' increased language awareness gained from exposure to language variation in a community of diverse ethnic, sociolinguistic, and geographic backgrounds. Another common theme that emerges is how interactions with diverse speakers help develop students' own language skills and, in turn, build their linguistic confidence. Also made evident are how hands-on community experiences allow students to construct positive identities as they engage in various new roles as expert and facilitator, validating their service-learning work and strengthening their ties to the community. These analyses also demonstrate how through service-learning, students engage in bilingual language and identity practices, making meaning and developing positive attitudes toward their communities, their language, and what it means to be bilingual.

In the following excerpt, Beatriz discusses her exposure to different language varieties while completing her service-learning activities:

\section{Excerpt 1}

Mi experiencia trabajando con los niños y padres de la comunidad latina de Greensboro me ha ayudado con el español. He practicado mas el español durante el servicio a la comunidad que en casa. Estuve expuesta a muchos dialectos cuando fui a cada casa. Con los padres de los niños use la forma usted cuando me dirigía a ellos. Note que en cada hogar tienen variedades lingüisticas diferentes para expresar lo que sienten y lo que piensan. Le pregunte a las madres de donde eran y dos de ellas eran de México y una era de El Salvador. Aunque dos de las madres eran de México podía notar una diferencia lingüística. Esta diferencia era por la variedad geográfica. Una de ellas era del sur y la otra era del centro de México. La otra madre era de El Salvador y ella usaba el voseo. En mi casa no usamos el voseo. Fue un poco difícil al principio tratar de entender a la señora. Con el tiempo me acostumbre un poco mas. Era una diferencia en el uso del vocabulario, gramática y fonológica que notaba en cada casa. Note que cada persona usa ciertas palabras para expresarse y los niños usan el mismo vocabulario que sus padres.

My experience working with the children and parents of the Latino community of Greensboro has helped me with Spanish. I have practiced Spanish more during my service learning than at home. I was exposed to many dialects when I went to each home. With the children's parents I used the Usted form when I addressed them. I noticed that in each home there were different linguistic varieties to express what they feel and what they think. I asked the mothers where they were from and two of them were from Mexico and one was from El Salvador. Although two of the mothers were from Mexico I could notice a linguistic difference. This difference was due to geographical variation. One of 
them was from the south and the other was from the center of Mexico. The other mother was from El Salvador and used vos (el voseo). In my home we do not use vos. It was a little bit difficult at the beginning to try to understand the woman. Over time, I got more used to it. There was a difference in vocabulary, grammar and phonology that I noticed in each home. I noticed that each person used certain words to express him/herself and the children used the same vocabulary as their parents.

First, Beatriz describes an increase in her HL use, due to speaking Spanish at her new servicelearning site. Course objectives to increase HL use and expand HL use to new social contexts are, thus, being met for this student. Second, Beatriz exercises agency in her linguistic choices during her service-learning encounter when she chooses to use the Usted form when addressing the children's parents. This is an important goal of the SHL course, and it resonates with Martinez's (2003) classroom based dialect awareness model aimed to give HL students the tools and the confidence to make their own linguistic choices in real-life interactions.

Also noteworthy in this excerpt is that Beatriz describes her exposure to language variation using a variety of linguistic terrminology: variedades lingüísticas (language varieties), variedad geográfica (geographical variation), el voseo (use of the pronoun vos), vocabulario (vocabulary), gramática (grammar), diferencia fonológica (phonological difference), etc. This is evidence that Beatriz is applying the linguistic concepts she has learned in class and is becoming more aware of these linguistic phenomena as they occur in her daily service-learning interactions. Her increased language awareness allows her to acknowledge sociolinguistic variation, like el voseo, and lexical and phonetic differences among local community members, children and parents alike.

Service-learning importantly generates awareness of cultural and linguistic diversity. The excerpt that follows highlights how Beatriz's activities lead to her greater awareness of the diversity of Latinos:

\section{Excerpt 2}

Esta experiencia me hizo entender que no todos venimos del mismo origen. Aun que muchos de los hispanos tengamos las mismas características, no todos somos del mismo país. Conocí a mucha gente que eran de otros países de Latino América. Muchos se distinguían por su forma de hablar. Algunos hablan mas rápido que otros. Otros hablan mas lento pero aun puedo notar que tienen un dialecto distinto. Me alegro de que aunque haya variedad lingüística puedo seguir comunicándome con los niños y los padres sin malos entendidos y puedo usar el cambio de códigos.

This experience made me realize that we don't all have the same origins. Although many Hispanics have the similar characteristics, we are not all from the same country. I met a lot of people from other countries in Latin America. Many distinguished themselves by their way of speaking. Some spoke faster than others. Others spoke slower but I could still notice that they had a 
different dialect. I am happy that despite the language variation I could continue communicating with the children and parents without misunderstandings and I could use code-switching.

Above, Beatriz expresses how the experience helped her recognize that the Latino community is not homogenous and that people have different forms of speaking, including different linguistic characteristics and rates of speech, respective of their countries of origin. More importantly, she realizes that despite these linguistic differences, she is able to communicate with the families without misunderstandings. Through her interactions with linguistically diverse speakers she builds linguistic confidence. Beatriz remarks that she is happy to be able to use code-switching at the site. She has found a new context in which she can comfortably express her bilingual identity. At the same time, she is experiencing firsthand the value of code-switching in this new context, a way of speaking that increases understanding and is helping her community members. This further attests to the confidence she is building in her bilingual language practices.

Similarly, in Excerpt 3 below, another student, Berta, expresses a new appreciation for the rich linguistic diversity of her community and how this exposure has helped her express herself better in Spanish, surprising herself. This excerpt also illuminates how Berta's service activities afford her opportunities to construct a new identity, as an expert, when community children ask for her help with Spanish and she imparts her knowledge, helping them learn the words in their HL. Engaging in this role as expert aids in increasing Berta's confidence in her own language skills. It also helps Berta forge her membership in a competent bilingual community:

\section{Excerpt 3}

El servicio a la comunidad si me ah ayudado bastante con mi español. Me he dado cuenta que se expresarme usando español mucho mejor de lo que yo creía y también mejoré. En lo que use más el español fue en la guardería donde trabaja mi mamá, ahí iban muchas madres hispanas ah sus clases de inglés y cuando no entendían algo yo ayudaba a interpretar. Se me hizo curioso que muchas de las mamás no eran de México, y es ahí donde aprendí el español de muchos acentos diferentes. Me gusta la idea de que siendo un mismo lenguaje puede haber tanta diversidad en la forma de hablar y las palabras diferentes que se usan para algunas cosas. También me gusta poder ayudar a niños que no entienden o hablan muy bien el español. En muchas ocasiones niños de más grande edad me preguntaban como se decía algo en español y claro yo podía decirles, y les daba gusto saber la palabra.

The community service has helped me a lot with my Spanish. I have realized that I know how to express myself better than I thought and I also improved. Where I used Spanish the most was in the daycare where my mom works, there many Hispanic moms went to their English classes and when they didn't understand something I helped to interpret. I found it interesting that many of the moms were not from Mexico and that's when I learned that Spanish has many different accents. I like the fact that being the same language there is a lot of diversity in the way of speaking and in the different words they use for 
some things. I also like to be able to help children who don't understand or don't understand Spanish very well. On many occasions, older children would ask me how to say something in Spanish and of course I could tell them and it made them happy to know the word.

An increased awareness of the struggles of Latino families is evident in Excerpt 4, in which Berta recognizes that these children's heritage language maintenance is affected by the long hours their parents must work and the little time they have to teach and practice the language together. This validates Berta's service-learning efforts and affirms her identity role as facilitator in helping the children to maintain their heritage language.

\section{Excerpt 4}

Son esas pequeñas cosas que me alegran el día y que hacen que me encante ayudar a la comunidad hispana. Y mucho más porque sé que muchos de estos niños no pueden pasar mucho tiempo con sus papás porque trabajan mucho y siento que a veces es por eso que los jóvenes no hablan muy bien el español. Pero es muy importante saber hablar los dos idiomas, ser bilingüe viene con muchos beneficios.

It's these little things that make my day and that make me love to help the Hispanic community. And even more because I know that many of these children cannot spend much time with their parents because they work a lot and I feel that at times it is for this reason that young people don't speak Spanish very well. But it is important to know two languages, being bilingual brings many benefits.

Excerpt 4 above also reveals how the service-learning experience affirms the value of being bilingual for Berta. Witnessing how the children are struggling with maintaining their HL reinforces the value of knowing both languages and helps drive Berta's commitment to helping these youngsters. Positive attitudes such as these developed here help foster HL maintenance.

Exposure to different language varieties can also provide valuable communication skills in general, as exemplified in Excerpt 5 by Carla, who affirms that such exposure has taught her how to be patient and a good listener. Acquisition of these skills form part of the SHL course objectives, making service-learning an effective pathway to HL acquisition and maintenance. Moreover, Carla describes how the experience with different dialects has given her more confidence as a Spanish speaker. She remarks that at first it was difficult, but that with time and effort it became easier for her to understand. Carla's experience truly highlights how the process endured through exposure to language variation, and the sense of accomplishment when language forms and varieties different from one's own are understood have a positive impact on one's self-confidence:

\section{Excerpt 5}

En el centro de Oakwood, hay mucha diversidad. Hay personas de todas partes del mundo, y hay muchos dialectos diferentes. A veces era difícil entender diferentes dialectos de personas que visitaban el centro, pero al pasar el tiempo, 
se me hizo mucho más fácil. Algunas mamás hablaban muy rápido en sus dialectos y muchas veces era muy difícil entenderlas. Pero siempre encontré una manera de seguir la conversación y entender todo lo que fue dicho en cada conversación. No siempre fue fácil, pero esta experiencia me enseno a tener más paciencia conmigo misma.

At the Oakwood Center there is a lot of diversity. There are people from all around the world and there are many different language varieties. At times it was hard to understand the different language varieties of people that visited the center but as time when on it became much easier. Some of the moms spoke very fast in their varieties and many times it was difficult to understand them. But I always found a way to follow the conversation and understand everything that was said in every conversation. It wasn't always easy but this experience taught me to be more patient with myself.

The intrinsic link between language and identity is clearly illustrated in Excerpts 6 and 7. Service-learning, through building language skills and confidence, can help HL learners to regain a lost sense of identity, as was the case for Carla below. Carla's numerous references to feeling embarrassed or ashamed (avergonzada) and having forgotten (había olvidado) her language and culture demonstrate the strong connections between language, culture and identity for Carla, like for many other HL speakers. Carla describes below how forgetting her language truly frightened her:

\section{Excerpt 6}

Personalmente, yo creo que este proyecto de servicio a la comunidad me ha ayudado mucho con mi español. Mi experiencia lingüística ha sido muy positiva durante este proyecto. Yo siempre he sido muy tímida cuando hablo español aquí en los Estados Unidos. Cuando yo llegue a este país, yo aprendi el inglés muy rápido, y esto causo que olvidara un poco el español. Yo nunca pensé que me olvidaría tanto de mi primera lengua y esto me asusto mucho. Me asusto tanto que me sentí avergonzada por olvidarlo tan rápido. Me sentí avergonzada de mi misma, y del hecho que había olvidado parte de mi cultura.

Personally, I think this service-learning project has helped me a lot with my Spanish. My language experience has been very positive during this project. I always have been very shy when I speak Spanish here in the United States. When I arrived to this country, I learned English very quickly and this made me lose Spanish a little bit. I never thought that I would forget my first language and it really scared me. I felt ashamed of myself, and of the fact that I had forgotten part of my culture.

Yet Carla recognizes how the service-learning experience has helped her to recover her Hispanic identity in Excerpt 7. Carla explicitly links this to making her feel more confident (más segura). Through service-learning, Carla's identity transforms, from an ashamed, unconfident speaker to a confident, competent speaker of Spanish: 


\section{Excerpt 7}

Desde el día que me di cuenta de esto, decidí recuperar mi identidad hispana. Por eso es que creo que esta experiencia me ha ayudado tanto. Yo pienso que ir a este centro para ayudar a los niños ha sido algo muy positivo. Me gustó mucho ayudar a estas personas y estos niños aunque sea un poco. Tanto como yo pienso que los ayude a ellos, ellos me han ayudado a mí. La práctica que obtenía cuando los ayudaba me convirtió en una persona más segura. Ahora, me siento más segura cuando hablo español en público, y con mis familiares y amigos. Esto se siente bien.

Since the day I realized that, I decided to regain my Hispanic identity. That is why I believe this experience has helped me so much. I think that going to the center to help the children has been something very positive. I liked a lot helping these people and these children even if it is only a little bit. As much as I think that I helped them, they have helped me. The practice I got when I was helping them converted me into a more confident person. Now I feel more confident when I speak Spanish in public, and with my family members and friends. It feels good.

This excerpt also reflects Carla's exercise of agency in enrolling in the SHL service-learning course to study her HL and recover her lost sense of identity.

\section{CONCLUSION}

In sum, this study contributes to an important gap in research on the impacts of service-learning in the SHL context. The current study provides evidence that students' hands-on experiences with language variation in HL communities aid in the development of students' language skills, linguistic confidence and the construction of positive attitudes and identities.

Quantitative analysis of student questionnaires shows that, overall, students felt more connected to their local Latino communities as a result of their service-learning experience and the majority of students felt their service-learning experience had a positive influence on their communities as well as their own lives. Service-learning also increased students' awareness of social issues affecting the local community.

Qualitative content analysis of student reflections, on the other hand, highlighted the complex ways language and identity are intertwined as students' language abilities and attitudes impact the way they feel about their communities, their language and themselves. Students' language awareness increased through linguistic exchanges with ethnically, geographically and sociolinguistically diverse community members, and through making connections with sociolinguistic concepts they learned in class, altogether helping them make sense of themselves and their communities. Analysis of reflections also revealed that service-learning experiences afforded students opportunities to increase their HL use and be agents in their linguistic choices in the community, including stylistic and register choices as well as bilingual language practices like code-switching. Overall, this study's findings support service-learning as an effective critical pedagogy for HL learners. When thoughtfully designed and fully integrated with other classroom materials, assignments, reflections and discussions, service-learning has the potential to address many of the pedagogical challenges of this special group of learners. 
Still, further research on the intersection of service-learning and HL learning is needed. Research questions that future studies in this area should address include: How does service-learning impact learners' language attitudes toward Spanish, including learners' local varieties of Spanish? What is the impact of service-learning on language maintenance for learners and communities? In what ways can service-learning be optimized to meet students' learning needs? How can service-learning be conducted to most effectively meet shared community goals? Investigation of these topics will help educators devise service-learning projects and courses that foster positive outcomes for learners and communities alike.

\section{Pedagogical Implications}

This service-learning study on SHL learners was guided by recent research on language, identity and language ideology and is a step forward, toward the development of effective pedagogies that generate critical language awareness, promote student agency and foster positive language attitudes and identities in the SHL classroom. Fellow educators are urged to turn to local communities as resources in accomplishing the shift toward a 'language as resource' approach and in the development of critical HL pedagogies.

Following the initiatives of HL educators who have combined LSP classes with service-learning, as Martinez (2010) and Morín (2010) have done, for example, with medical Spanish, servicelearning experiences can prepare students for their future professions. Even if courses are not LSP courses, specifically, service-learning can still be designed to enhance students' academic and professional goals. For example, in the case of the current study, many students enrolled in the advanced SHL course had aspirations to become licensed teachers of Spanish, choosing the specialized Spanish with teaching licensure track in the major. Service-learning activities such as tutoring and mentoring immigrant youth naturally coincided with students' future professional plans to become teachers, and aided in the development of their teaching and guidance skills as they worked with diverse young learners in the community. Thus, by establishing diverse community partnerships and offering students service-learning opportunities in multiple fields (e.g., education, law, healthcare, business, language interpretation etc.), educators can help align students' professional interests with service-learning activities. This is not only rewarding to students but it is beneficial for communities as well to have students working in their own area of interest and growing expertise.

Another important pedagogical consideration to make regarding service-learning courses concerns course credit. The current study's service-learning course did not offer any additional course credits toward the major or graduation requirements. However, the majority of student participants in the current study maintained jobs in addition to being full-time students. Also, while the overwhelming majority of students reported that they were satisfied with their servicelearning experience and would like to continue to serve the community in the future, some students acknowledged that with their busy schedules they might not have time to do so. Perhaps if institutions and programs offered additional academic credits for service-learning courses, it would encourage more student participation in service-learning and foster stronger ties between academic institutions and communities. 
Finally, critical pedagogy must go beyond demonstrating the legitimacy of students' language varieties and promoting student agency in language choices (Leeman, 2005). Students must also be encouraged to "explore (a) the relationship between power and language and the sociopolitical reasons that certain language varieties and practices are frequently constructed as inferior or unacceptable, (b) the ways in which these constructions are propagated, and (c) the consequences for speakers of varieties negatively constructed" (Leeman, 2005, p 42). Leeman (2005) reviews some very useful activities used by her and other researchers to help illuminate linguistic subordination and facilitate students' critical exploration of language ideologies, conventions and policies. In my own service-learning classes I have had students conduct minisociolinguistic projects in the community in which they observe, record and analyze community language use as well as their own language use. This is a great way to initiate students' critical reflection of the value of different language varieties in different linguistic exchanges, including their own local language varieties. Mini-projects such as these also encourage students' critical examination of the production and reproduction of dominant linguistic hierarchies and how to challenge such hierarchies. Students who develop critical language awareness can recognize and understand their own role in upholding or challenging dominant linguistic hierarchies, which can foster students' agency in their linguistic choices. This, in turn, contributes to increased confidence in language choices and the construction of positive language attitudes and identities.

\section{ACKNOWLEDGEMENTS}

I would like to sincerely thank the reviewers and editors of the Heritage Language Journal for their valuable feedback. I am especially grateful to Dr. Netta Avineri and Dr. Andrew Lynch for their insightful comments and suggestions.

\section{REFERENCES}

Achugar, M., \& Pessoa, S. (2009). Power, history and place: language attitudes towards Spanish in a bilingual academic community in Southwest Texas. Spanish in Context, 6(2), 199-223.

Beaudrie, S. (2015). Approaches to language variation: Goals and objectives of the Spanish heritage language syllabus. The Heritage Language Journal, 12(1), 1-21.

Beebe, R. M., \& De Costa, E. M. (1993). Teaching beyond the classroom: The Santa Clara Eastside Project - Community service and the Spanish classroom. Hispania, 16(4), 884-91.

Blommaert, J. (1999). The debate is open. In J. Blommaert (Ed.), Language ideological debates (pp. 1-38). Berlin, Germany: Mouton de Gruyter.

Blommaert, J., \& Verschueren, J. (1998). The role of language in European nationalist ideologies. In B. Schieffelin, K. Woolard, and P. Kroskity, (Eds.), Languageideologies: Practice and theory (pp. 189-210). New York, NY: Oxford University Press.

Bourdieu, P. (1991). Language and symbolic power. Cambridge, MA: Harvard University Press.

Boyle, J. P. \& Overfield, D. M. (1999). Community-based language learning: Integrating language and service. In J. Hellebrandt \& L. T. Varona (Eds.), Construyendo puentes [building bridges]: Concepts and models for service-learning in Spanish (pp. 137-147). Washington, DC: American Association for Higher Education.

Caldwell, W. (2007). Taking Spanish outside the box: A model for integrating service learning into foreign language study. Foreign Language Annals, 40, 463-471. 
Carreira, M. (2000). Validating and promoting Spanish in the United States: Lessons from linguistic science. Bilingual Research Journal, 24(4), 423-42.

Carreira, M. (2003). Profiles of SNS students in the $21^{\text {st }}$ century: Pedagogical implications of the changing demographics and social status of U.S. Hispanics. In A. Roca \& M.C. Colombi (Eds.), Mi lengua: Spanish as a heritage language in the United States (pp.51-77). Washington, D.C.: Georgetown University Press.

Carreira, M., \& Kagan, O. (2011). The results of the National Heritage Language Survey: Implications for teaching, curriculum design, and professional development. Foreign Language Annals, 43(3), 40-64.

Ducar, C. (2008). Student voices: The missing link in the heritage language debate. Foreign Language Annals, 4l(3), 415-33.

Ducar, C. (2009). The sound of silence: Spanish heritage textbooks' treatment of language variation. In M. Lacorte \& J. Leeman (Eds.), Español en Estados Unidos y otros contextos de contacto: Sociolinguistica, ideología, y pedagogía (pp. 347-367). Madrid: Ibéroamerica.

Ducar, C. (2012). SHL learners' attitudes and motivations. In S. Beaudrie \& M. Fairclough (Eds.), Spanish as a heritage language in the United States: The state of the field (pp. 161178). Washington, D.C.: Georgetown University Press.

Draper, J., \& Hicks, J. (2000). Where we've been; what we've learned. In J. Webb \& B. Miller (Eds.), Teaching heritage language learners: Voices from the classroom (pp. 15- 35). Yonkers, NY: American Council on the Teaching of Foreign Languages.

Ennis, S. R., Rios-Vargas, M., \& Albert, N. G. (2011). The Hispanic population: 2010. 2010 Census Briefs, C2010BR-04. Washington, DC: U.S. Census Bureau. Retrieved from http://www.census.gov/prod/cen2010/briefs/c2010br-04.pdf

Eyler J., Giles D. E., \& Schmiede, A. (1996). A practitioner's guide to reflection in servicelearning: Student voices \& reflections. Nashville, TN: Vanderbilt University.

Fairclough, N. (1992). Critical language awareness. New York, NY: Taylor \& Francis.

Fishman, J. A. (2006). Three hundred-plus years of heritage language education in the United States. In G. Valdés, J.A. Fishman, R. Chávez, \& W. Pérez (Eds.), Developing minority language resources: The case of Spanish in California (pp. 12-23). Tonawanda, NY: Multilingual Matters.

Friedrich, P. (1989). Language, ideology, and political economy. American Anthropologist, 91(2), 295-312.

Gal, S. (1989). Language and political economy. Annual Review of Anthropology, 18, 345-367.

Gal, S. (1998). Multiplicity and contestation among linguistic ideologies. In K. Woolard \& B. Schieffelin, (Eds.), Language ideologies: Practice and theory (pp. 317-331). New York, NY: Oxford University Press.

Gal, S., \& Woolard, K. (1995). Constructing languages and publics: Authority and representation. Pragmatics, 5(2), 129-183.

Hellebrandt, J., Arries, J., \& Varona, L. (Eds.) (2003). Juntos: Community partnerships in Spanish and Portuguese. Boston, MA: Heinle and Heinle.

Hellebrandt, J. \& Jorge, E. (Eds.) (2013). Hispania Special Focus Issue: The Scholarship of Community Engagement, 96(2).

Hellebrandt, J., \& Varona, L. (Eds.) (1999). Construyendo Puentes: Concepts and Models for Service-Learning in Spanish. Washington, DC: American Association for Higher Education. 
Howard, J. (Ed.) (2001). Service-learning course design workbook. Michigan Journal of Community Service Learning, Companion Volume. Ann Arbor, MI: OCSL Press.

Irvine, J. T. (1989). When talk isn't cheap: Language and political economy. American Ethnologist, 16(2), 248-267.

Jaffe, A. (2007). Minority language movements. In M. Heller (Ed.), Bilingualism: A social approach (pp. 50-70). New York, NY: Palgrave Press.

Kroskrity, P. (1998). Arizona Tewa Kiva speech as a manifestation of a dominant language ideology. In B. Schieffelin, K. Woolard, \& P. Kroskrity (Eds.), Language ideologies: Practice and theory (pp. 103-122). New York, NY: Oxford University Press.

Lafford, B., Abbott, A. \& Lear, D. (2014). Spanish in the professions and in the community in the US. Journal of Spanish Language Teaching, 1(2), 171-186.

Lear, D., \& Abbott, A. (2008). Foreign language professional standards and CSL: Achieving the 5 C's. Michigan Journal of Community Service Learning, 14(2), 76-86.

Leeman, J. (2005). Engaging critical pedagogy: Spanish for native speakers. Foreign Language Annals, 38(1), 35-45.

Leeman, J. (2012). Investigating language ideologies in Spanish as heritage language. In S. Beaudrie \& M. Fairclough (Eds.), Spanish as a heritage language in the United States: The state of the field (pp. 43-59). Washington DC: Georgetown University Press.

Leeman, J., \& Martínez, G. (2007). From identity to commodity: Ideologies of Spanish in heritage language textbooks. Critical Inquiry in Language Studies, 4(1), 35-65.

Leeman, J., Rabin, L., \& Román-Mendoza, E. (2011). Identity and activism in heritage language education. Modern Language Journal, 95(4), 481-495.

Lynch, A. (2012). Key concepts for theorizing Spanish as a heritage language. In S. Beaudrie \& M. Fairclough (Eds.), Spanish as a heritage language in the United States: The state of the field (pp. 79- 97). Washington, D.C.: Georgetown University Press.

Lowther Pereira, K. A. (2010). Identity and language ideology in the intermediate Spanish heritage language classroom (Doctoral dissertation). Retrieved from ProQuest Dissertations and Theses. (Accession Order No. AAT 3402888)

Martínez, G. (2003). Classroom based dialect awareness in heritage language instruction: A critical applied linguistic approach. Heritage Language Journal, 1(1), 1-14.

Martínez, G. (2010). Medical Spanish for heritage learning learners: A prescription to improve the health of Spanish-speaking communities. In S. Rivera-Mills \& J. A. Trujillo (Eds.), Building communities and making connections (pp. 3-15). Chapel Hill, NC: Cambridge Scholars Publishing.

Martínez, G., \& Schwartz, A. (2012). 'Elevating "low" language for high stakes: A case for critical, community-based learning in a medical Spanish for heritage learners program. Heritage Language Journal, 9(2), 37-49.

Mollica, A., Nuessel, F. \& Cedeno, A. (2004). Current trends and issues in service learning in the Spanish curriculum. Mosaic, 8(3), 10-16.

Morin, R. (2010). Making connections: Spanish for medical purposes and service learning. In S. Rivera-Mills \& J. A. Trujillo (Eds.), Building communities and making connections (pp. 1639). Chapel Hill, NC: Cambridge Scholars Publishing.

Morris, F. (2001a). Enhancing motivation and promoting positive attitudes toward second language learning through community experience. In G. Bräuer (Ed.), Pedagogy of language learning in higher education: An introduction (pp. 47-60). Westport, CT: Ablex. 
Morris, F. (2001b). Serving the community and learning a foreign language: Evaluating a service-learning program. Language, Culture and Curriculum, 14, 244-55.

Pellettieri, J. (2011). Measuring language-related outcomes of community-based learning in intermediate Spanish courses, Hispania, 94, 285-302.

Kochhar, R., Suro, R., \& Tafoya, S. (2005). The new Latino south: The context and consequences of rapid population growth. Philadelphia, PA, and Washington, DC: Pew Charitable Trusts. Retrieved from http://www.pewtrusts.org/en/research-andanalysis/reports/2005/07/26/the-new-latino-south-the-context-and-consequences-of-rapidpopulation-growth

Krippendorff, K. (2004). Content analysis: An introduction to its methodology (2 ${ }^{\text {nd }}$ ed.). New York, NY: Sage Publishing.

Potowski, K. (2004). Student Spanish use and investment in a dual immersion classroom: Implications for second language acquisition and heritage language maintenance. Modern Language Journal, 88(1), 75-101.

Potowski, K. (2005). Fundamentos de la enseñanza del español a hispanohablantes en los EE.UU [Fundamentals of teaching Spanish to Spanish speakers in the United States]. Madrid: Arco/Libros.

Potowski, K. (2012). Identity and heritage learners. In S. Beaudrie \& M. Fairclough (Eds.), Spanish as a heritage language in the United States: The state of the field (pp. 179- 199). Washington, D.C.: Georgetown University Press.

Rivera-Mills, S R. (2010). Building communities and making connections in the $21^{\text {st }}$ century: A new role for higher education. In S. Rivera-Mills \& J. A. Trujillo, (Eds), Building communities and making connections (pp: i-xv). Chapel Hill, NC: Cambridge Scholars Publishing.

Ruiz, R. (1984). Orientations in language planning. National Association for Bilingual Education Journal, 8, 15-34.

Ruiz, R. (2010). Reorienting language-as-resource. In J. E. Petrovic (Ed.), International perspectives on bilingual education: Policy, practice, and controversy (pp. 155-172). Charlotte, NC: Information Age Publishing.

Sánchez-Muñoz, A. (2007). Style variation in Spanish as a heritage language: A study of discourse particles in academic and non-academic registers. In K. Potowski \& R. Cameron (Eds.), Spanish in contact: Policy, social and linguistic inquiries (pp. 153-172). Amsterdam, Netherlands: John Benjamins.

Office of Leadership \& Service Learning. (n.d.) Service-learning: High Impact service-learning at UNCG. Greensboro, NC: The University of North Carolina at Greensboro. Retrieved from http://olsl.uncg.edu/service-learning/

Silva-Corvalán, C. (1994). Language contact and change: Spanish in Los Angeles. Oxford, UK: Oxford University Press.

Thomspon, G. (2012). The intersection of service and learning: Research and practice in the second language classroom. Charlotte, NC: Information Age Publishing.

Urciouli, B. (2008). Whose Spanish? The tension between linguistic correctness and cultural identity. In M. Niño-Murcia \& J. Rothman (Eds.), Bilingualism and identity: Spanish at the crossroads with other languages (pp. 257-277). Amsterdam, Netherlands: John Benjamins Publishing Company. 
U.S. Census Bureau, Population Division. (March, 2014). Annual Estimates of the Resident Population: April 1, 2010 to July 1, 2013 - United States -- Combined Statistical Area; and for Puerto Rico. Available from http://factfinder.census.gov

Valdés, G. (1981). Pedagogical implications of teaching Spanish to the Spanish-Speaking in the United States. In G. Valdés, A. Lozano, \& R. García-Moya, (Eds.), Teaching Spanish to the Hispanic bilingual: Issues, aims, and methods (pp. 3-20). New York, NY: Teachers College Press.

Valdés, G. (1995). The teaching of minority languages as "foreign" languages: Pedagogical and theoretical challenges. Modern Language Journal, 79(3), 299-328.

Valdés, G. (2001). Heritage language students: Profiles and possibilities. In J. Peyton, D. Ranard, \& S. McGinnis (Eds.), Heritage languages in America: Preserving a national resource (pp. 37-77). McHenry, IL: Center for Applied Linguistics. Washington, DC: CAL, ERIC; [McHenry, IL]: Delta Systems Co., Inc.

Varona, L. T. (1999). La comunidad en el aula y el aula en la comunidad: Un modelo. Hispania, 82(4), 806-816.

Villa, D. (1996). Choosing a 'standard' variety of Spanish for the instruction of native Spanish speakers in the U.S. Foreign Language Annals, 29, 191- 200.

Villa, D. (2002). The sanitizing of U.S. Spanish in academia. Foreign Language Annals, 35(2), 222-230.

Villa, D. (2010). ¿¡Cómo que Spanglish!? Creating a service learning component for a Spanish heritage language program. In S. Rivera-Mills \& J. A. Trujillo (Eds.), Building communities and making connections (pp. 120-135). Chapel Hill, NC: Cambridge Scholars Publishing.

Weldon, A. and Trautmann, G. (2003). Spanish and service-learning: Pedagogy and praxis. Hispania, 86(3), 574-585.

Woolard, K. (1998). Introduction: Language ideology as a field of inquiry. In B. Schieffelin, K. Woolard, and P. Kroskity, (Eds.), Language ideologies: Practice and theory (pp. 3-47). New York, NY: Oxford University Press.

Zapata, G. (2011). The effects of community service learning projects on L2 learners'cultural understanding. Hispania, 94(1), 86-102. 


\section{NOTES}

1. It should be noted that in order to capture the most accurate picture of students' overall ties to the community, the series of survey questions on this topic purposefully vary slightly in wording. For example, question 3 refers to students" "connectedness to the community" whereas question 5 refers to "sense of belonging." While on the surface these two questions appear to be similar, students who commute to UNCG and do not reside in the Triad/Greensboro, for example, might respond differently.

2. It should be noted that excerpts from student journals are unedited and appear exactly as written by the students. In addition, pseudonyms have been used to protect the identity of the study participants. 